\title{
IMPACT OF STAND DENSITY ON SOIL QUALITY IN CHINESE FIR (CUNNINGHAMIA LANCEOLATA) MONOCULTURE
}

\author{
FAROOQ, T. H. ${ }^{1,2}-$ MA, X. ${ }^{1,2}-$ RASHID, M. H. U. ${ }^{1,2}-$ WU, W. ${ }^{1,2}-$ XU, J. ${ }^{1,2}-$ TARIN, M. W. K. ${ }^{1}-$ \\ HE, Z. ${ }^{1}-\mathrm{WU}, \mathrm{P}^{1,2^{*}}$ \\ ${ }^{1}$ Forestry College, Fujian Agriculture and Forestry University \\ Fuzhou, 350002 Fujian Province, PR China
}

${ }^{2}$ Fujian Provincial Colleges and University Engineering Research Center of Plantation Sustainable Management, Fuzhou, 350002 Fujian Province, PR China

*Corresponding author

email: fjwupengfei@126.com, fjwupengfei@fafu.edu.cn; phonelfax: +86-591-8378-0261

(Received $30^{\text {th }}$ Nov 2018; accepted $18^{\text {th }}$ Feb 2019)

\begin{abstract}
It is known that forest management practices and land use affect soil quality worldwide. This study was conducted to assess the potential effects of stand density on soil quality in Chinese fir plantations. Low- (1,450 trees/ha with $2.36 \times 2.36 \mathrm{~m}$ spacing), intermediate- $(2,460$ trees/ha with $1.83 \times$ $1.83 \mathrm{~m}$ spacing), and high-density (3,950 trees/ha with $1.44 \times 1.44 \mathrm{~m}$ spacing) stands in a 10-year-old Chinese fir monoculture plantation were examined, and different soil quality indicators were measured. The results indicated that stand density affected nitrogen $(\mathrm{N})$, phosphorous $(\mathrm{P})$, and magnesium $(\mathrm{Mg})$ content, whereas potassium $(\mathrm{K})$ and calcium $(\mathrm{Ca})$ were not affected. Total $\mathrm{N}$ and total $\mathrm{P}$ contents were higher in the low-density stands, whereas total $\mathrm{Mg}$ was higher in the intermediate-density stands. Available $\mathrm{N}$ was higher in the low-density stands, whereas available $\mathrm{P}$ was higher in the intermediatedensity stands. No significant difference was observed in the contents of available K, total K, and total Ca among all densities. Soil organic matter was significantly higher in the intermediate-density stand than in the high- and low-density stands. Soil bulk density increased from the surface layer to the 40-60 cm soil layer. Soil $\mathrm{pH}$ was lowest in the surface layer of soils of all three densities and increased from the 0$20 \mathrm{~cm}$ layer to the $20-40 \mathrm{~cm}$ layer; however, it decreased from the $20-40 \mathrm{~cm}$ layer to the $40-60 \mathrm{~cm}$ layer. Soil $\mathrm{pH}$ differed significantly between soils of different densities but remained within an optimum range (4.1-4.5) for Chinese fir plantations. Soil moisture content was significantly higher in the high-density stand than the other stands. The observed effects of stand density on soil quality may be useful for policy makers and forest managers to implement improved forest conservation practices for preserving soil quality and stand production.
\end{abstract}

Keywords: forest conservation, soil health, sustainable forestry, nutrient status, competition

Abbreviations: SOM-soil organic matter, SMC-soil moisture content, BD-soil bulk density, $\mathrm{DBH}$-diameter at breast height, $\mathrm{TN}$-total nitrogen, $\mathrm{TP}$-total phosphorus, $\mathrm{TK}$-total potassium, TCa-total calcium, $\mathrm{TMg}$-total magnesium, $\mathrm{AN}$-available nitrogen, $\mathrm{AP}$-available phosphorus, $\mathrm{AK}$-available potassium, EC-soil electrical conductivity, SO-silty oxisol

\section{Introduction}

Chinese fir (Cunninghamia lanceolata (Lamb) Hook) is an indigenous, typically evergreen, sub-tropical conifer species, and it is a widely cultivated timber specie in China due to its high yield, excellent timber quality, and fast growth. According to the Eighth National Forest Inventory, the planting area of Chinese fir covers more than 11 million ha, which accounts for about $18.2 \%$ of all forest plantations in China, and for $6 \%$ of the global forest plantation area (State Forestry Administration, 2014). The yield of Chinese fir plantations has declined continuously over the past years (Yang et al., 2005a), and standing wood volumes in the second and third rotations were $30 \%$ and 
$47 \%$ less those in the first rotation, respectively (Bi et al., 2007). Serious concerns have been raised regarding the decrease in yield and the long-term decline in the productivity of Chinese fir (Ma et al., 2007; Zhao et al., 2013; Zhou et al., 2015). In other countries such as Brazil, deforestation rates are either decreasing or stabilizing; however, in China, Malaysia, and Indonesia, deforestation rates are increasing due to the increasing demand for wood-derived products (Margono et al., 2014; Abood et al., 2015).

In forest research, soil quality monitoring has been recognized as a primary aspect for sustainable management. Soil quality can vary due to management and land use practices, which is strongly correlated with physio-chemical, bio-chemical, and biological soil properties (Dudley et al., 2014). Land over-use and intensive cultivation resulted in millions of ha of degraded land, and soil erosion has led to the loss of topsoil and exposure of soils with low nutrient content (Liu and Zhao, 1993; Wei et al., 2006; Zhou et al., 2006). For commercial purposes such as timber production, deforestation continues to be carried out globally on a large scale, leading to significant decreases in soil quality and ecosystem productivity, and Chinese fir plantations are no exception (Wang et al., 2014).

In Chinese fir plantations, surface soil hydrolysable nitrogen $(\mathrm{N})$ and available phosphorous (P) declined under continuous cropping (Horner et al., 2010). Various studies demonstrated a reduction in soil nutrient availability, microbiome structure, microbial enzyme activity (Yang et al., 2010; Vitali et al., 2016; Wang et al., 2017; Zhang et al., 2017b), N stocks, and soil organic carbon after conversion of native forests to plantations (Chen et al., 2013; Marin-Spiotta and Sharma, 2013; Guan et al., 2015; van Straaten et al., 2015). Therefore, a decline in timber yield and productivity under the current management practices of Chinese fir plantations is likely a response to impoverished soils.

Soil quality indicators have been assessed in previous studies in different regions of China with the main research focus on different provenances or age of the plantations. These studies are useful, however, there is no comprehensive understanding of soil quality in Chinese fir stands of different planting densities. The current study was conducted to fill this gap by studying different soil quality indicators in Chinese fir monoculture plantations of the same age (ten years) but with different stand densities. The soil quality parameters total soil nutrient and available nutrient content, soil organic matter content (SOM), soil pH, soil bulk density (BD), and soil moisture content (SMC) were analyzed at low-, intermediate- and high-density stands. We hypothesized (1) that due to competition by higher under-story vegetation and higher number of trees in lowand high-density stands respectively, total and available nutrient content should be higher in intermediate-density stands; (2) that stand density should have no effect on soil $\mathrm{pH}$ and electrical conductivity (EC), while SOM and SMC should be higher in high-density stands than in low- and intermediate-density stands due to maximum shade and less sun light availability.

\section{Materials and methods}

\section{Study site}

The Xinkou Experimental Forest Farm was established in 2007 as Chinese fir monoculture plantations, in Sanming City, Fujian Province, China (Fig. 1). The study site was located at $26^{\circ} 10^{\prime} \mathrm{N}$ and $117^{\circ} 27^{\prime}$ E. Soils were acidic and the climate of the region was a typical mid-subtropical monsoon climate (Zhou et al., 2015), with mean 
annual rainfall of $1,612 \mathrm{~mm}$ and a mean annual temperature of $19{ }^{\circ} \mathrm{C}$, according to an on-site meteorological station. The average monthly temperature and precipitation is shown in Table 1. Before the plantation was established, the area was cut clear, the debris was piled and burned, and complete tillage was carried out. After this, the surface biomass was burned before establishing stands, and one-year-old Chinese fir seedlings were planted. Three plantation stands with different densities were selected and categorized as low-, intermediate-, or high-density stands. The understory vegetation in the selected Chinese fir stands were Maesa japonica, Woodwardia japonica, Callicarpa kochiana, Selaginella moellendorffii, Ilex pubescens, and Alpinia japonica. Further details on the plantation stands are shown in Table 2.

\section{Soil sampling}

Soil was sampled in the second week of November 2017. Four plots of $20 \times 20 \mathrm{~m}$ were established in each stand, and in each plot, four pits were dug diagonally. A soil corer was used to obtain soil samples from 0-20, 20-40, and 40-60 cm depths from each pit. After collection, the soil samples from the four sampling pits were mixed to produce one sample for each soil layer and measure $\mathrm{pH}$. Eight composite samples per density from a 0-60 $\mathrm{cm}$ depth were prepared to measure the total and available nutrient content, SOM, and SMC. All samples were sealed in clean, air-tight polythene bags. Three soil samples were collected from each stand to determine soil BD at 0-20, 20-40, and 40-60 cm depths using $200 \mathrm{~cm}^{3}$ volumetric rings.

Table 1. Average monthly temperature and precipitation in Sanming City, Fujian, China

\begin{tabular}{c|c|c|c|c}
\hline & $\begin{array}{c}\text { Average } \\
\text { temperature }\left({ }^{\circ} \mathbf{C}\right)\end{array}$ & $\begin{array}{c}\text { Minimum } \\
\text { temperature }\left({ }^{\circ} \mathbf{C}\right)\end{array}$ & $\begin{array}{c}\text { Maximum } \\
\text { temperature }\left({ }^{\circ} \mathbf{C}\right)\end{array}$ & $\begin{array}{c}\text { Average } \\
\text { precipitation }(\mathbf{m m})\end{array}$ \\
\hline January & 10.4 & 5.9 & 14.9 & 57 \\
February & 11.4 & 7.3 & 15.5 & 101 \\
March & 15.2 & 10.9 & 19.6 & 180 \\
April & 19.9 & 15.4 & 24.4 & 203 \\
May & 23.6 & 19.4 & 27.9 & 279 \\
June & 26.5 & 22.1 & 31.0 & 276 \\
July & 28.8 & 23.7 & 34.0 & 122 \\
August & 28.4 & 23.4 & 33.4 & 134 \\
September & 26.1 & 21.5 & 30.8 & 108 \\
October & 21.3 & 16.5 & 26.1 & 63 \\
November & 16.7 & 12.1 & 21.3 & 49 \\
December & 11.3 & 6.5 & 16.1 & 40 \\
\hline
\end{tabular}

Table 2. Details of plantation stands. Shown are the means $\pm S E$ values of average height and diameters at breast height (DBH). "SO" indicates the soil type silty oxisol

\begin{tabular}{c|c|c|c|c|c|c}
\hline Stand density & $\begin{array}{c}\text { Number of } \\
\text { trees/ha }\end{array}$ & Spacing (m) & $\begin{array}{c}\text { Altitude } \\
\text { (a.s.l) }\end{array}$ & Avg. DBH (cm) & $\begin{array}{c}\text { Avg. height } \\
(\mathbf{m})\end{array}$ & Soil type \\
\hline Low & 1,450 & $2.36 \times 2.36$ & 206 & $13.05 \pm 0.12$ & $12.41 \pm 0.14$ & SO \\
Intermediate & 2,460 & $1.83 \times 1.83$ & 204 & $12.46 \pm 0.43$ & $12.01 \pm 0.30$ & SO \\
High & 3,950 & $1.44 \times 1.44$ & 210 & $11.04 \pm 0.19$ & $11.63 \pm 0.23$ & SO \\
\hline
\end{tabular}



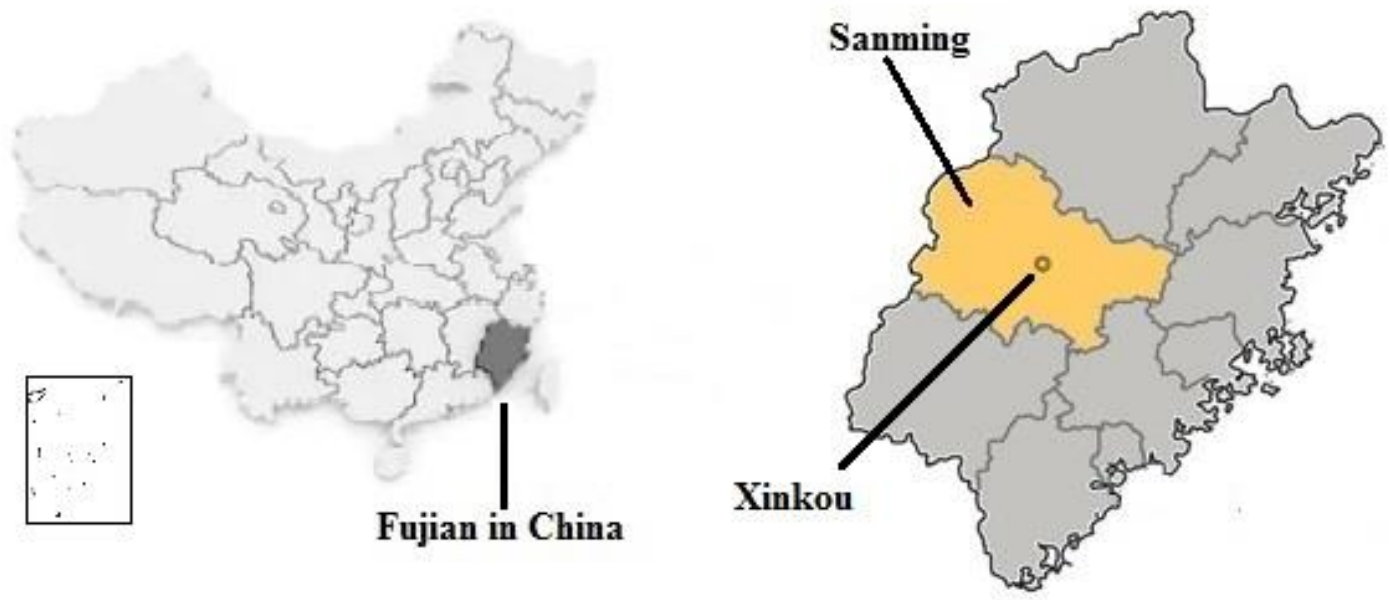

Figure 1. Location of the study area, Xinkou Experimental Forest Farm, in Sanming City, Fujian province, China

\section{Sample preparation}

All samples were transferred to a laboratory for further analyses. Debris and roots were removed carefully by hand. The soil samples were air-dried at room temperature and then crushed and passed through sieves of $2 \mathrm{~mm}$ and $0.15 \mathrm{~mm}$ mesh size for subsequent analyses. To determine soil BD, the samples were weighed and then dried to constant weight before re-weighing.

\section{Laboratory analyses}

All measurements were conducted in the key laboratory of soil and water conservation, College of Forestry, Fujian Agriculture and Forestry University, China. The respective analysis methods are shown in Table 3.

Table 3. Methods and equipment used for soil quality analyses

\begin{tabular}{c|c}
\hline Analysis & Method/Equipment \\
\hline pH & Potentiometric method (1:2.5 soil:water) \\
Electrical conductivity (EC) & Conductivity meter \\
Bulk density (BD) & Core method of the Nanjing Institute of Soil Science (1978) \\
Total nitrogen & CN elental analyzer \\
Total phosphorus & Molybdenum-antimony colorimetric method \\
Total potassium & Flame photometry \\
Total calcium & CN elemental analyzer \\
Total magnesium & CN elemental analyzer \\
Available nitrogen & Kjeldahl method (Ryan et al., 2007) \\
Available phosphorus & Bray and Kurtz (1945) \\
Available potassium & Schollenberger and Simon (1945) \\
C:N ratio & CN elemental analyzer \\
Moisture content (SMC) & Calculated based on wet and dry weight \\
Soil organic matter (SOM) & Soil organic carbon was first measured by wet oxidation (CN \\
elemental analyzer) and then calculated as SOM
\end{tabular}




\section{Statistical analyses}

All measurements are reported as mean \pm standard error. A one-way analysis of variance was used to determine correlations between soil quality indicators and stand densities using the SPSS software (SPSS 13.0, SPSS Inc., IL, USA). Means of variables that showed significant differences were compared using Tukey's test at a 5\% level of significance. Origin 9.1 and ArcGis software were used to produce graphs and figures.

\section{Results}

\section{Variation in total soil nutrient contents}

A significant difference in total $\mathrm{N}$ and $\mathrm{P}$ contents between stands was observed at $P<0.05$. Total $\mathrm{N}$ content was $0.99 \pm 0.2 \mathrm{~g} / \mathrm{kg}, 0.74 \pm 0.1 \mathrm{~g} / \mathrm{kg}$, and $0.92 \pm 0.08 \mathrm{~g} / \mathrm{kg}$, and total P content was $0.59 \pm 0.03 \mathrm{~g} / \mathrm{kg}, 0.48 \pm 0.1 \mathrm{~g} / \mathrm{kg}$, and $0.59 \pm 0.2 \mathrm{~g} / \mathrm{kg}$ in low-, intermediate- and high-density stands, respectively. Both total $\mathrm{N}$ and total $\mathrm{P}$ contents were highest in the low-density stand and lowest in the intermediate-density stand.

Total Mg contents were highest in intermediate-density stand and lowest in the lowdensity stand. No significant differences between stand densities were found in total $\mathrm{K}$ and $\mathrm{Ca}$ contents. Total $\mathrm{K}$ contents were $22.5 \pm 7.5 \mathrm{~g} / \mathrm{kg}, 21.2 \pm 8.2 \mathrm{~g} / \mathrm{kg}$, and $21.8 \pm$ $2.5 \mathrm{~g} / \mathrm{kg}$ and total $\mathrm{Mg}$ contents were $7.41 \pm 3.9 \mathrm{~g} / \mathrm{kg}, 8.51 \pm 3.7 \mathrm{~g} / \mathrm{kg}$, and $7.91 \pm$ $0.5 \mathrm{~g} / \mathrm{kg}$ in low-, intermediate-, and high-density stands, respectively. Total Ca contents were $2.23 \pm 0.4 \mathrm{~g} / \mathrm{kg}, 2.25 \pm 1.09 \mathrm{~g} / \mathrm{kg}$, and $2.14 \pm 0.9 \mathrm{~g} / \mathrm{kg}$ in low-, intermediate-, and high-density stands, respectively (Fig. 2).

\section{Variability in available soil nutrient contents}

Available $\mathrm{N}$ and available $\mathrm{P}$ were significantly different between soils of different stand densities, whereas available $\mathrm{K}$ contents did not differ significantly. Available $\mathrm{N}$ contents in soils of low-, intermediate- and high-density stands were $67.69 \pm 2.2 \mathrm{mg} / \mathrm{kg}$, $59.04 \pm 3.0 \mathrm{mg} / \mathrm{kg}$, and $54.07 \pm 1.9 \mathrm{mg} / \mathrm{kg}$, respectively, and available P contents were $3.92 \pm 0.2 \mathrm{mg} / \mathrm{kg}, 5.16 \pm 0.4 \mathrm{mg} / \mathrm{kg}$, and $4.79 \pm 0.5 \mathrm{mg} / \mathrm{kg}$, respectively. Available $\mathrm{K}$ contents in soils of low-, intermediate- and high-density stands were $87.23 \pm 2.1 \mathrm{mg} / \mathrm{kg}$, $81.44 \pm 3.9 \mathrm{mg} / \mathrm{kg}$, and $87.30 \pm 5.4 \mathrm{mg} / \mathrm{kg}$, respectively.

Available $\mathrm{N}$ was highest in the low-density stand and lowest in high-density stand, whereas available $\mathrm{P}$ was highest in the intermediate-density stand lowest in the lowdensity stand. Available $\mathrm{K}$ did not differ significantly between the low- and highdensity stand, both of which differed significantly from the intermediate-density stand (Fig. 3).

\section{Soil pH, BD, SOM, EC, and SMC}

Modest variations in the $\mathrm{pH}$ values were observed between stands in each soil layer (Fig. 4a). Soil pH in the 0-20 $\mathrm{cm}$ soil layer was $4.21 \pm 0.1,4.28 \pm 0.04$, and $4.27 \pm 0.2$ in the low-, intermediate-, and high-density stands, respectively. The soil $\mathrm{pH}$ values in the 20-40 cm soil layer were $4.27 \pm 0.03,4.37 \pm 0.02$, and $4.29 \pm 0.1$, respectively. In the 40-60 cm layer, the $\mathrm{pH}$ values were $4.15 \pm 0.04,4.28 \pm 0.02,4.27 \pm 0.1$ in the low-, intermediate-, and high-density stands, respectively. The soil $\mathrm{pH}$ values in the $0-20 \mathrm{~cm}$ layer was lower in intermediate- and high-density stands compared to the $20-40 \mathrm{~cm}$ and 40-60 cm layers (Fig. 4a). Soil pH was higher in the 20-40 cm layer and lower in the 
40-60 cm layer. There was no consistent decline from the 0-20 and 40-60 cm layers in the intermediate- and high-density stands, however, these layers differed significantly different in the low-density stand.

Soil BD generally increased with increasing stand density, which was consistent in the $0-20 \mathrm{~cm}, 20-40 \mathrm{~cm}$, and 40-60 cm soil layers (Fig. $4 b$ ). In the surface layer, soil BD was $1.06 \pm 0.1 \mathrm{~g} / \mathrm{m}^{3}, 1.24 \pm 0.04 \mathrm{~g} / \mathrm{m}^{3}$, and $1.36 \pm 0.2 \mathrm{~g} / \mathrm{m}^{3}$, and in the $20-40 \mathrm{~cm}$ layer soil BD was $1.19 \pm 0.2 \mathrm{~g} / \mathrm{m}^{3}, 1.24 \pm 0.1 \mathrm{~g} / \mathrm{m}^{3}$ and $1.34 \pm 0.3 \mathrm{~g} / \mathrm{m}^{3}$ in low-, intermediate-, and high-density, respectively. Furthermore, in the 40-60 cm layer, soil BD was $1.04 \pm$ $0.1 \mathrm{~g} / \mathrm{m}^{3}, 1.15 \pm 0.3 \mathrm{~g} / \mathrm{m}^{3}$, and $1.29 \pm 0.1 \mathrm{~g} / \mathrm{m}^{3}$ in the low-, intermediate-, and highdensity stand, respectively. In the surface layer, soil BD differed significantly between stands and increased from the low- to the high-density stand. Soil BD in the 20-40 cm and 40-60 cm layers was higher in the high-density stand and lowest in low-density stand (Fig. 4b).
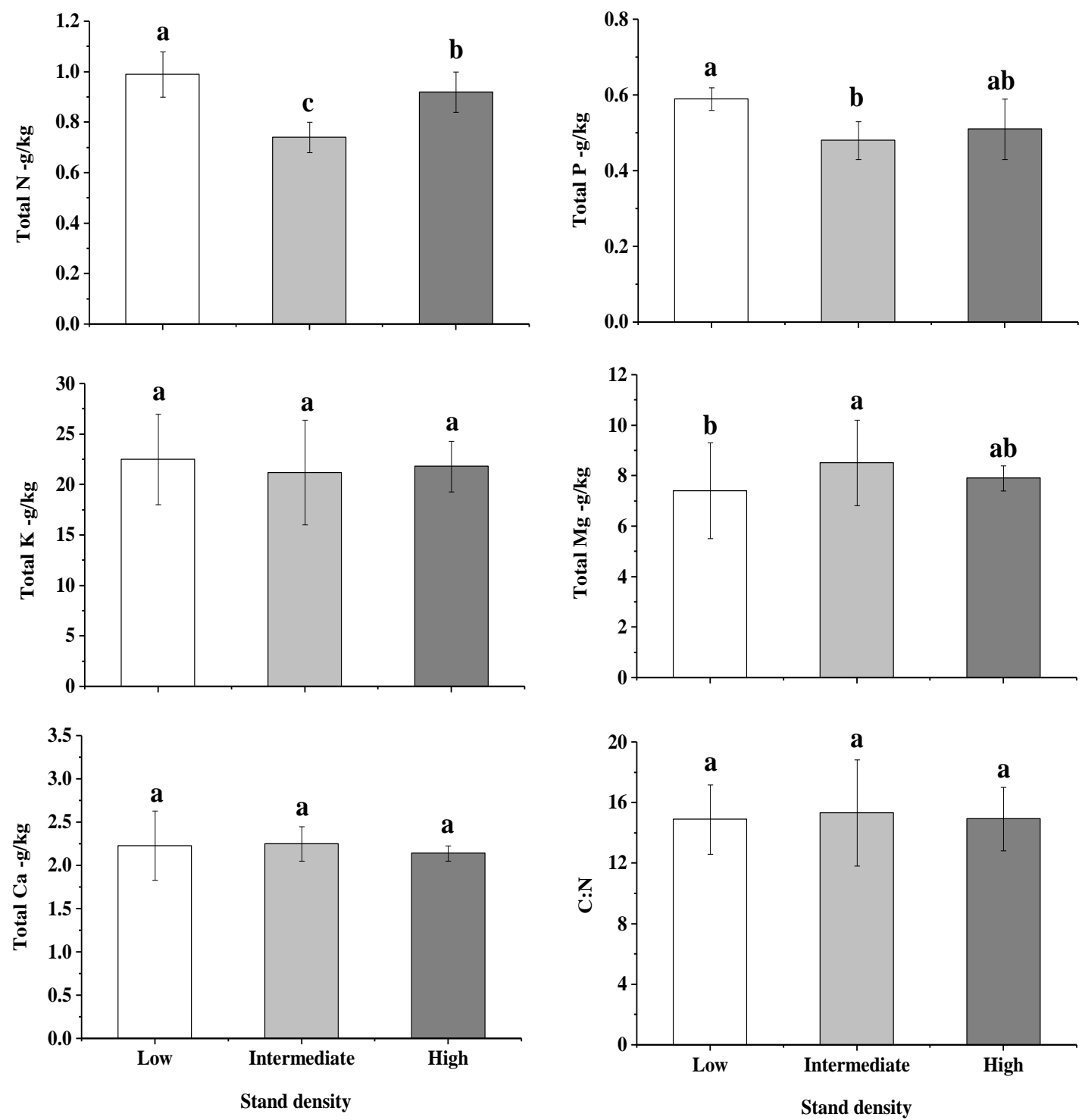

Figure 2. Variation among total soil nutrient contents in low-, intermediate-, and high-density stands $(N=24)$. Columns indicate mean $\pm S E$, different letters indicate significant differences at $P<0.05$ 

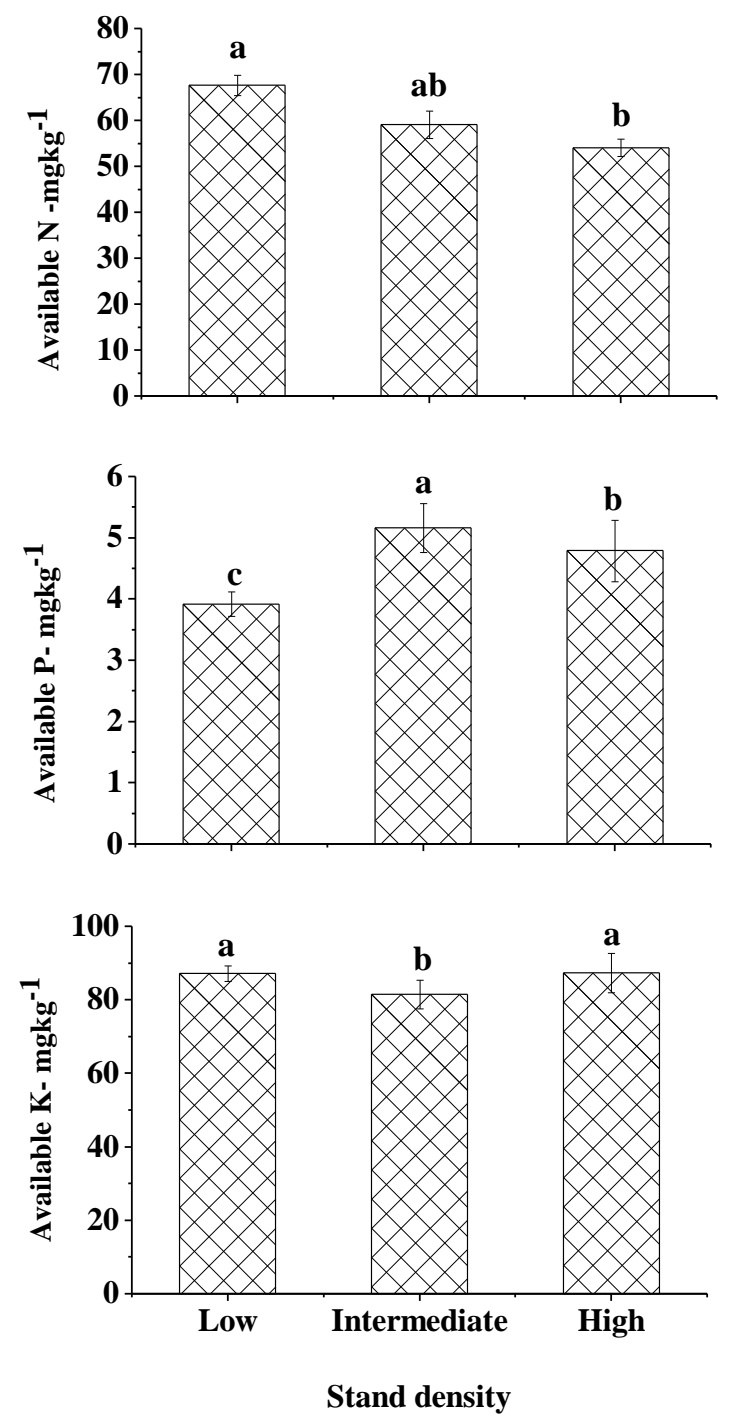

Figure 3. Available $N$, available $P$, and available $K$ at low-, intermediate-, and high-density stands $(N=24)$. Columns indicate mean $\pm S E$, different letters indicate significant differences at $P<0.05$

At a 0-60 $\mathrm{cm}$ soil depth, the soil $\mathrm{pH}$ was highest in the intermediate-density stand and lowest in the low-density stand. In both the intermediate- and the high-density stands the soil $\mathrm{pH}$ values were significantly different from the low-density stand. Soil $\mathrm{pH}$ values were $4.21 \pm 0.04,4.31 \pm 0.03$, and $4.27 \pm 0.03$ in the low-, medium- and high-density stands, respectively. Soil BD was highest in the intermediate-density stand and lowest in the high-density stand. Soil BD was $1.22 \pm 0.07,1.28 \pm 0.01$, and $1.16 \pm$ 0.09 in low-, medium-, and high-density stands, respectively, and differed significantly between stands (Table 4).

No significant difference in soil EC was observed among the stands. SOM was higher in the intermediate-density stand and lower in low-density stand; the SOM values were $31.90 \pm 1.34 \mathrm{~g} / \mathrm{kg}, 36.56 \pm 1.61 \mathrm{~g} / \mathrm{kg}$, and $35.47 \pm 0.8 \mathrm{~g} / \mathrm{kg}$ in the low-, intermediate-, and high-density stands, respectively. No significant difference was observed between the intermediate- and high-density stands; however, both were significantly different from the low-density stand. SMC was higher $(17.2 \%)$ in the high- 
density stand than in the intermediate- $(9.53 \%)$ and low-density $(11.49 \%)$ stands. SMC in the high-density stand differed significantly from the intermediate- and the lowdensity stands (Table 4).
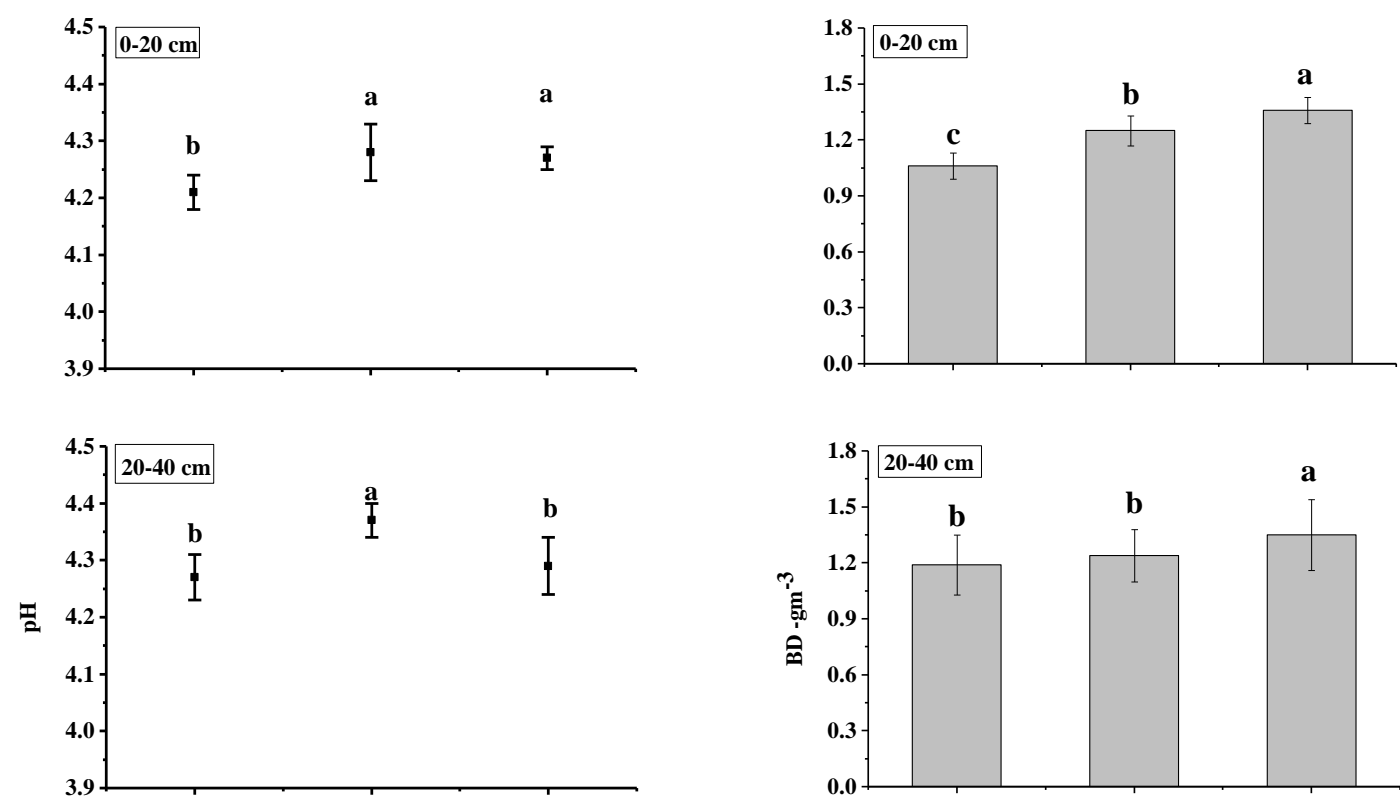

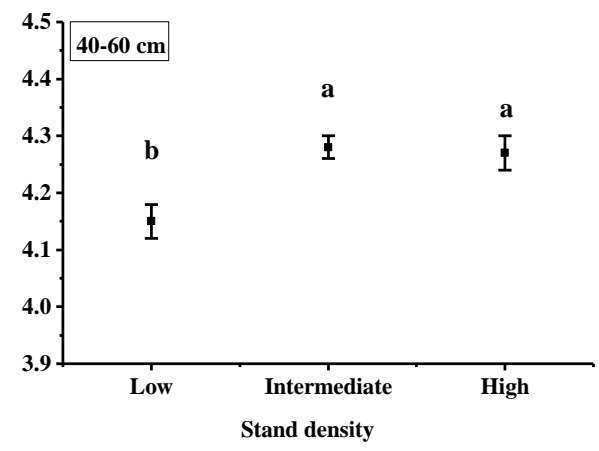

a

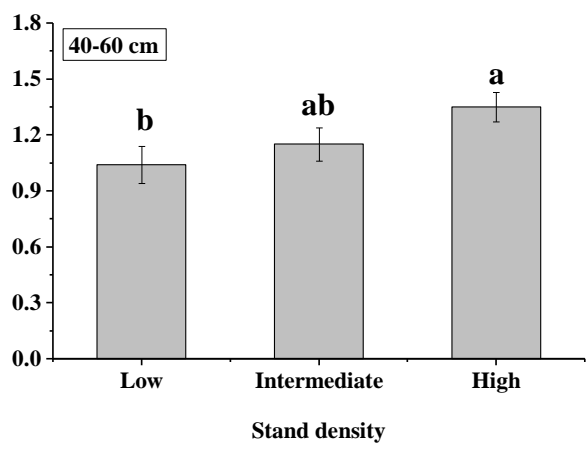

b

Figure 4. Soil $p H$ and soil BD in low-, intermediate-, and high-density stands. Columns indicate mean $\pm S E$, different letters indicate significant differences among densities at $P<0.05$

Table 4. Soil pH, soil electrical conductivity $(E C)$, soil bulk density $(B D)$, soil organic matter (SOM) and soil moisture content (SMC) in low-, intermediate-, and high-density stands at a $0-60 \mathrm{~cm}$ soil depth $(N=24)$

\begin{tabular}{c|c|c|c}
\hline \multirow{2}{*}{ Soil parameters } & \multicolumn{3}{|c}{ Stand density } \\
\cline { 2 - 4 } & Low & Intermediate & High \\
\hline $\mathrm{pH}$ & $4.21 \pm 0.04 \mathrm{~b}$ & $4.31 \pm 0.03 \mathrm{a}$ & $4.27 \pm 0.03 \mathrm{a}$ \\
$\mathrm{BD}\left(\mathrm{g} / \mathrm{m}^{3}\right)$ & $1.22 \pm 0.07 \mathrm{ab}$ & $1.28 \pm 0.01 \mathrm{a}$ & $1.16 \pm 0.09 \mathrm{~b}$ \\
$\mathrm{EC}$ & $0.02 \pm 0.01 \mathrm{a}$ & $0.02 \pm 0.01 \mathrm{a}$ & $0.02 \pm 0.01 \mathrm{a}$ \\
$\mathrm{SOM}(\mathrm{g} / \mathrm{kg})$ & $31.90 \pm 1.34 \mathrm{~b}$ & $36.56 \pm 1.61 \mathrm{a}$ & $35.47 \pm 0.74 \mathrm{a}$ \\
$\mathrm{SMC}(\%)$ & $11.49 \mathrm{~b}$ & $9.53 \mathrm{~b}$ & $17.2 \mathrm{a}$ \\
\hline
\end{tabular}

Note: Shown are the mean $\pm \mathrm{SE}$, different letters indicate significant differences between the stands at $P<0.05$ 


\section{Discussion}

In forest conservation and management, stand density is an important factor influencing the trees' competition for growth space, light, and below-ground resources (nutrients and water) (Farinelli and Lemos, 2012; Fan et al., 2014; Sitienei et al., 2016). The soil quality indicators used in the current study were successfully used in previous studies on different forest ecosystems (Kay and Grant, 1996; Wei et al., 2009; BautistaCruz et al., 2012; Zhijun et al., 2018), suggesting that these parameters can be used for effective soil quality evaluation.

Watt et al. $(2005,2008)$ identified total $\mathrm{P}$ as important soil quality indicator due to its pivotal role in biochemical reactions and in the nutrient cycling of plantation systems (Reganold and Palmer, 1995; Turrión et al., 2007). In the present study, stand density had a significant effect on total $\mathrm{N}$, available $\mathrm{N}$, total $\mathrm{P}$, available $\mathrm{P}$, and total $\mathrm{Mg}$ but had no significant effect on total $\mathrm{Ca}$, total $\mathrm{K}$, and available $\mathrm{K}$. In these plantations of ten years of age, both total $\mathrm{N}$ and total $\mathrm{P}$ were higher in the low-density stand and lower in the intermediate-density stand. Available $\mathrm{N}$ content was higher in the low-density stand and lower in the high-density stand, whereas available $\mathrm{P}$ content was higher in the intermediate-density stand and lower in the low-density stand. Our results contradicted those of Fang et al. (2017) who found that stand density had no significant effect on total soil $\mathrm{N}$ and on $\mathrm{C}: \mathrm{N}$ ratio. Cancellier et al. (2011) reported that varying planting density influenced the soil chemical properties, and in low planting density, available $\mathrm{P}$ and exchangeable $\mathrm{Mg}, \mathrm{N}$, and $\mathrm{Ca}$ concentrations were significantly higher than at other planting densities, but little difference was observed in soil organic matter content. Furthermore, our results support the assumption that total $\mathrm{P}$ is an important indicator of soil quality for conifer plantations (Yang et al., 2004; Ma et al., 2007; Ross et al., 2009).

SOM acts as a storage reservoir for soil nutrients and is an important parameter for assessing sustainable forest management (Haynes and Beare, 1996; Tanaka et al., 2005). Availability of $\mathrm{C}$ and $\mathrm{N}$ in soil is crucial regarding SOM and abundance of the microbial biomass (Xing et al., 2010; Zhang et al., 2017a). According to our results, SOM was affected by stand density and was significantly higher in the intermediate-density stand than in the other stands. Moreover, previous studies showed that in Chinese fir plantations SOM increased due to a large quantity of debris input following artificial thinning (Lin et al., 2001; Ma et al., 2014). Besides stand population density, continuous rotations can also have a significant impact on soil fertility (Black, 2013). Huang et al. (2004) stated that in Chinese fir plantations SOM decreased significantly with continuous cultivation (by $10 \%$ and $15 \%$ in second and third rotation, respectively). Soil enzyme activity and microbial diversity decreased with successive rotations (Chen and Wang, 2003; Liu et al., 2010). According to a different study, continuous planting does not necessarily affect soil degradation, SOM, total P, total K, and available N content; it was therefore hypothesized that sustainability and soil fertility could be consolidated under a continuous cropping regime if plantation stand density was optimized (Wei et al., 2012). In contrast to our results, Wright (1992) reported that plant density has no substantial effect on soil fertility. Taken together, the relationship of plant density and soil fertility seems not to be entirely consistent.

Soil $\mathrm{pH}$ is an important indicator of soil quality, influencing plant nutrient availability and soil chemical reactions (Schoenholtz et al., 2000; Cheng et al., 2016). Previous studies have emphasized the importance of $\mathrm{pH}$ as a soil quality indicator for assessing different land use and forest conservation practices (Doran and Parkin, 1994; Bautista-Cruz et al., 2012; Yu et al., 2017). Soil pH was lowest in the surface layer of 
soils of all three densities and increased from the 0-20 cm layer to the $20-40 \mathrm{~cm}$ layer; however, it decreased from the $20-40 \mathrm{~cm}$ to $40-60 \mathrm{~cm}$ layer. No significant difference in $\mathrm{pH}$ was observed between intermediate-density and high-density stands, both of which differed significantly from the low-density stand; however, the $\mathrm{pH}$ values generally remained within the optimum range for Chinese fir plantations (Zhou, 1985). Soil BD increased from the surface to the 40-60 cm soil layer, and significant differences between the stands were observed in each layer. Our results differed from those of Fang et al. (2017) who found that stand density had no significant effect on soil $\mathrm{pH}$ and BD.

The understanding of stand density and soil heath under continuous cropping conditions have become important for understanding forest productivity, plant population dynamics, and land use for sustainable production (de Bello et al., 2010; Van der Putten et al., 2013). Nutrients are typically removed from growing sites due to stem harvesting and clear cutting (Chen et al., 2013). Yang et al. (2005b) found that nutrient removal due to clear-cutting was higher than that due to pre-burning; furthermore, the total $\mathrm{N}$ and organic $\mathrm{C}$ contents of topsoil were reduced by $19 \%$ and $17 \%$, respectively. Therefore, besides fertilization, plant residues should be buried on site to replenish the soil nutrient contents. A lack of sufficient soil remediation may lead to a reduction in soil nutrient availability, which may, in turn, limit harvesting potential to only a few rotations (Zhou et al., 2016).

\section{Conclusions}

Assessing the effect of stand density may help maintain and enhance sustainable crop production and soil health. Our results indicated that stand density had a significant impact on total and available $\mathrm{N}$ and $\mathrm{P}$ but not on total and available $\mathrm{K}$. Moreover, total $\mathrm{Ca}$ was not affected by stand density. Total $\mathrm{P}$ may be a useful indicator for assessing soil quality in Chinese fir plantations. A significant difference in soil $\mathrm{pH}$ between stand densities was observed; however, soil $\mathrm{pH}$ was within the optimum range for Chinese fir plantations. Soil BD was higher in the intermediate-density stand, and SMC was higher in the high-density stand; SOM was higher in the intermediate-density stand and lower in the low-density stand. No significant difference in the SOM was found between intermediate- and high-density stands, both of which were significantly different from the low-density stand. Soil nutrients typically decline due to clear cutting; therefore, the residues should be buried on site to increase soil fertility. A long-term strategy for maintaining and improving yield and sustainable land use requires that policy makers and managers have access to information on the quantitative relationship between stand density and soil quality. To preserve soil quality and ensure high timber production, variations in soil quality parameters, which are affected by stand density, may help policy makers develop better management practices. Moreover, the influence of aspects, such as enzymatic activity, biological variables and microbiological communities, on soil functioning should also be investigated.

Acknowledgements. This study was financially supported by the National Natural Science Foundation of China (31870614 and 31370531), the Science and Technology Major Project of Fujian Province, China (2018NZ0001-1) and the Special Technology Innovation Foundation of Fujian Agriculture and Forestry University (CXZX2017112). 


\section{REFERENCES}

[1] Abood, S. A., Lee, J. S. H., Burivalova, Z., Garcia-Ulloa, J., Koh, L. P. (2015): Relative contributions of the logging, fiber, oil palm, and mining industries to forest loss in Indonesia. - Conservation Letters 8(1): 58-67.

[2] Bautista-Cruz, A., del Castillo, R. F., Etchevers-Barra, J. D., del Carmen GutiérrezCastorena, M., Baez, A. (2012): Selection and interpretation of soil quality indicators for forest recovery after clearing of a tropical montane cloud forest in Mexico. - Forest Ecology and Management 277: 74-80.

[3] Bi, J., Blanco, J. A., Seely, B., Kimmins, J. P., Ding, Y., Welham, C. (2007): Yield decline in Chinese-fir plantations: a simulation investigation with implications for model complexity. - Canadian Journal of Forest Research 37(9): 1615-1630.

[4] Black, C. A. (2013): Soil Fertility Evaluation and Control. - CRC Press, Boca Raton, FL.

[5] Bray, R. H., Kurtz, L. T. (1945): Determination of total, organic, and available forms of phosphorus in soils. - Soil science 59(1): 39-46.

[6] Cancellier, L. L., Afférri, F. S., de Carvalho, E. V., Dotto, M. A., Leão, F. F. (2011): Nitrogen use efficiency and phenotypic correlations of tropical maize populations in Tocantins. - Revista Ciência Agronômica 42(1): 139-148.

[7] Chen, G. S., Yang, Z. J., Gao, R., Xie, J. S., Guo, J. F., Huang, Z. Q., Yang, Y. S. (2013): Carbon storage in a chronosequence of Chinese fir plantations in southern China. - Forest Ecology and Management 300: 68-76.

[8] Chen, L., Wang, S. (2003): Preliminary study of allelopathy of root exudates of Chinese fir. - Acta Ecologica Sinica 23(2): 393-398.

[9] Cheng, J., Ding, C., Li, X., Zhang, T., Wang, X. (2016): Soil quality evaluation for navel orange production systems in central subtropical China. - Soil and Tillage Research 155: 225-232.

[10] De Bello, F., Lavorel, S., Díaz, S., Harrington, R., Cornelissen, J. H. C., Bardgett, R. D. (2010): Towards an assessment of multiple ecosystem processes and services via functional traits. - Biodiversity and Conservation 19: 2873-2893.

[11] Doran, J. W., Parkin, T. B. (1994): Defining and Assessing Soil Quality. - In: Doran, J. W., Coleman, D. C., Bezdicek, D. F., Stewart, B. A. (eds.) Defining Soil Quality for a Sustainable Environment. Soil Science Society of America Journal, Madison, pp. 3-21.

[12] Dudley, N., Jeanrenaud, J. P., Sullivan, F. (2014): Bad Harvest: The timber Trade and the Degradation of Global Forests. - Taylor and Francis Ltd., UK.

[13] Fan, J., Wang, J. Y., Hu, X. F., Chen, F. S. (2014): Seasonal dynamics of soil nitrogen availability and phosphorus fractions under urban forest remnants of different vegetation communities in Southern China. - Urban Forestry \& Urban Greening 13(3): 576-585.

[14] Fang, X. M., Zhang, X. L., Zong, Y. Y., Zhang, Y., Wan, S. Z., Bu, W. S., Chen, F. S. (2017): Soil phosphorus functional fractions and tree tissue nutrient concentrations influenced by stand density in subtropical Chinese fir plantation forests. - PloS One 12(10).

[15] Farinelli, R., Lemos, L. B. (2012): Nitrogen in corn cover in conventional tillage and consolidated no-tillage. - Pesquisa Agropecuária Tropical 42: 63-70.

[16] Guan, F., Tang, X., Fan, S., Zhao, J., Peng, C. (2015): Changes in soil carbon and nitrogen stocks followed the conversion from secondary forest to Chinese fir and Moso bamboo plantations. - Catena 133: 455-460.

[17] Haynes, R. J., Beare, M. H. (1996): Aggregation and Organic Matter Storage in MesoThermal, Humid Soils. - In: Carter, M. R., Stewart, B. A. (eds.) Structure and Soil Organic Matter Storage in Agricultural Soils., CRC Press, Boca Raton, FL, pp. 213-262.

[18] Horner, G. J., Baker, P. J., Mac Nally, R., Cunningham, S. C., Thomson, J. R., Hamilton, F. (2010): Forest structure, habitat and carbon benefits from thinning floodplain forests: managing early stand density makes a difference. - Forest Ecology and Management 259(3): 286-293. 
[19] Huang, Y., Wang, S. L., Feng, Z. W., Ouyang, Z. Y., Wang, X. K., Feng, Z. Z. (2004): Changes in soil quality due to introduction of broad-leaf trees into clear-felled Chinese fir forest in the mid-subtropics of China. - Soil Use and Management 20(4): 418-425.

[20] Kay, B. D., Grant, C. D. (1996): Structural Aspects of Soil Quality. - In: MacEwan, R. J., Carter, M. R. (eds.) Soil Quality Is in the Hands of the Land Manager. University of Ballarat, Centre for Environmental Management, Victoria, Australia, pp. 37-41.

[21] Lin, K. M., Yu, X. T., Huang, B. L., He, Z. Y. (2001): Dynamical characteristics of undergrowth plant diversity in Chinese fir plantations. - Chinese Journal of Applied Ecology 7: 13-19 (in Chinese)

[22] Liu, L., Duan, Z., Xu, M., Hu, J., Wang, S., Hu, Z., Zhang, Q., Wang, S. (2010): Effect of monospecific and mixed Cunninghamia lanceolata plantations on microbial community and two functional genes involved in nitrogen cycling. - Plant and Soil 327(1-2): 413428.

[23] Liu, X. M., Zhao, H. L. (1993): Comprehensive Strategy for Eco-environmental Control in Horqin Sand Land. - Gansu Science and Technology Publishing-House, Lanzhou, China, pp. 88-115 (in Chinese).

[24] Ma, X., Heal, K. V., Liu, A., Jarvis, P. G. (2007): Nutrient cycling and distribution in different-aged plantations of Chinese fir in southern China. - Forest Ecology and Management 243(1): 61-74.

[25] Ma, Y. C., Piao, S. L., Sun, Z. Z., Lin, X., Wang, T., Yue, C., Yang, Y. (2014): Stand ages regulate the response of soil respiration to temperature in aLarix principisrupprechtii plantation. - Agricultural and Forest Meteorology 184: 179-187.

[26] Margono, B. A., Potapov, P. V., Turubanova, S., Stolle, F., Hansen, M. C. (2014): Primary forest cover loss in Indonesia over 2000-2012. - Nature Climate Change 4: 730735.

[27] Marin-Spiotta, E., Sharma, S. (2013): Carbon storage in successional and plantation forest soils: a tropical analysis. - Global Ecology and Biogeography 22: 105-117.

[28] Nanjing Institute of Soil Science (1978): Physical and Chemical Analysis of Soils. Science and Technology Press of Shanghai, Shanghai (in Chinese).

[29] Reganold, J. P., Palmer, A. S. (1995): Significance of gravimetric versus volumetric measurements of soil quality under biodynamic, conventional, and continuous grass management. - Journal of Soil Water Conservation 50: 298-305.

[30] Ross, C. W., Watt, M. S., Parfitt, R. L., Simcock, R., Dando, J., Coker, G., Clinton, P. W., Davis, M. R. (2009): Soil quality relationships with tree growth in exotic forests in New Zealand. - Forest Ecology and Management 258: 2326-2334.

[31] Ryan, J., Estefan, G., Rashid, A. (2007): Soil and Plant Analysis Laboratory Manual. ICARDA, Beirut.

[32] Schoenholtz, S. H., Van Miegroet, H., Burger, J. A. (2000): A review of chemical and physical properties as indicators of forest soil quality: challenges and opportunities. Forest Ecology and Management 138: 335-356.

[33] Schollenberger, C., Simon, R. (1945): Determination of exchange capacity and exchangeable bases in soil ammonium acetate method. - Soil Science 59: 13-24.

[34] State Forestry Administration (2014): General Situation of Forest Resources in China. The $8^{\text {th }}$ National Forest Inventory. - State Forestry Administration, Beijing.

[35] Sitienei, K., Kirui, K., Kamau, D., Wanyoko, J., Langat, K. (2016): Effect of plant density, nitrogen fertilizer application rates and soil depth on clonal tea soil nutrient content. - Journal of Tea Science Research. DOI: 10.5376/jtsr.2016.06.0007.

[36] Tanaka, S., Kendawang, J. J., Yoshida, N., Shibata, K., Jee, A., Tanaka, K., Ninomiya, I., Sakurai, K. (2005): Effects of shifting cultivation on soil ecosystems in Sarawak, Malaysia IV. Chemical properties of the soils and runoff water at Niah and Bakam experimental sites. - Soil Science \& Plant Nutrition, 51(4): 525-533. 
[37] Turrión, M., López, O., Lafuente, F., Mulas, R., Ruipérez, C., Puyo, A. (2007): Soil phosphorus forms as quality indicators of soils under different vegetation covers. Science of Total Environment 378: 195-198.

[38] Van der Putten, W. H., Bardgett, R. D., Bever, J. D., Bezemer, T. M., Casper, B. B., Fukami, T., Kardol, P., Klironomos, J. N., Kulmatiski, A., Schweitzer, J. A., Suding, K. N. (2013): Plant-soil feedbacks: the past, the present and future challenges. - Journal of Ecology 101(2): 265-276.

[39] Van Straaten, O., Corre, M. D., Wolf, K., Tchienkoua, M., Cuellar, E., Matthews, R. B., Veldkamp, E. (2015): Conversion of lowland tropical forests to tree cash crop plantations loses up to one-half of stored soil organic carbon. - Proceedings of the National Academy of Sciences of the United States of America 112: 9956-9960.

[40] Vitali, F., Mastromei, G., Senatore, G., Caroppo, C., Casalone, E. (2016): Long lasting effects of the conversion from natural forest to poplar plantation on soil microbial communities. - Microbiological Research 182: 89-98.

[41] Wang, J. C., Ren, C. Q., Cheng, H. T., Zou, Y. K., Bughio, M. A., Li, Q. F. (2017): Conversion of rainforest into agroforestry and monoculture plantation in China: Consequences for soil phosphorus forms and microbial community. - Science of Total Environment 595: 769-778.

[42] Wang, L., Zhang, Y., Berninger, F., Duan, B. (2014): Net primary production of Chinese fir plantation ecosystems and its relationship to climate. - Biogeosciences 11: 5595-5606.

[43] Watt, M. S., Coker, G., Clinton, P. W., Davis, M. R., Parfitt, R., Simcock, R., Garrett, L., Payn, T., Richardson, B., Dunningham, A. (2005): Defining sustainability of plantation forests through identification of site quality indicators influencing productivity- a national view for New Zealand. - Forest Ecology and Management 216: 51-63.

[44] Watt, M. S., Davis, M. R., Clinton, P. W., Coker, G., Ross, C., Dando, J., Parfitt, R., Simcock, R. (2008): Identification of key soil indicators influencing plantation productivity and sustainability across a national series in New Zealand. - Forest Ecology and Management 256: 180-190.

[45] Wei, J., Zhou, J., Tian, J., He, X. Tang, K. (2006): Decoupling soil erosion and human activities on the Chinese Loess Plateau in the 20th century. - Catena 68(1): 10-15.

[46] Wei, X., Blanco, J. A., Jiang, H., Kimmins, J. H. (2012): Effects of nitrogen deposition on carbon sequestration in Chinese fir forest ecosystems. - Science of the Total Environment 416: 351-361.

[47] Wei, Y. C., Ouyang, Z. Y., Miao, H., Zheng, H. (2009): Exotic Pinus carbaeacauses soil quality to deteriorate on former abandoned land compared to an indigenous Podocarpus plantation in the tropical forest area of southern China. - Journal of Forest Research 14: 221-228.

[48] Wright, S. J. (1992): Seasonal drought, soil fertility and the species density of tropical forest plant communities. - Trends in Ecology and Evolution 7(8): 260-263.

[49] Xing, S., Chen, C., Zhou, B., Zhang, H., Nang, Z., Xu, Z. (2010): Soil soluble organic nitrogen and active microbial characteristics under adjacent coniferous and broadleaf plantation forests. - Journal of Soils and Sediments 10(4): 748-757.

[50] Zhou, X. (1985): A preliminary survey of soil conditions in relation to the growth of Cunnighamia lanceolata. - Journal of Zhejiang Forestry College 2(1): 77-80 (in Chinese).

[51] Yang, K., Zhu, J. J., Yan, Q. L., Sun, J. X. (2010): Changes in soil P chemistry as affected by conversion of natural secondary forests to larch plantations. - Forest Ecology and Management 260: 422-428.

[52] Yang, Y., Liu, C., Kutsch, W., Chen, G., Yu, X. (2004): Impact of continuous Chinese fir monoculture on soil. - Pedosphere 14: 17-124.

[53] Yang, Y. S., Guo, J. F., Chen, G. S., Xie, J. S., Gao, R., Li, Z., Jin, Z. (2005a): Litter production, seasonal pattern and nutrient return in seven natural forests compared with a plantation in southern China. - Forestry 78(4): 403-415. 
[54] Yang, Y. S., Guo, J., Chen, G., Xie, J., Gao, R., Li, Z., Jin, Z. (2005b): Carbon and nitrogen pools in Chinese fir and evergreen broadleaved forests and changes associated with felling and burning in mid-subtropical China. - Forest Ecology and Management 216(1-3): 216-226.

[55] Yu, Y., Yang, J., Zeng, S., Wu, D., Jacobs, D. F., Sloan, J. L. (2017): Soil pH, organic matter, and nutrient content change with the continuous cropping of Cunninghamia lanceolata plantations in South China. - Journal of Soils and Sediments 17(9): 22302238.

[56] Zhang, W. W., Lu, Z. T., Yang, K., Zhu, J. J. (2017a): Impacts of conversion from secondary forests to larch plantations on the structure and function of microbial communities. - Applied Soil Ecology 111: 73-83.

[57] Zhang, Y., Wei, Z., Li, H., Guo, F., Wu, P., Zhou, L., Ma, X. (2017b): Biochemical quality and accumulation of soil organic matter in an age sequence of Cunninghamia lanceolata plantations in southern China. - Journal of Soils and Sediments 17(9): 22182229.

[58] Zhao, M., Xiang, W., Tian, D., Deng, X., Huang, Z., Zhou, X., Peng, C. (2013): Effects of increased nitrogen deposition and rotation length on long-term productivity of Cunninghamia lanceolata plantation in southern China. - Plos One 8(2).

[59] Zhijun, H., Selvalakshmi, S., Vasu, D., Liu, Q., Cheng, H., Guo, F., Ma, X. (2018): Identification of indicators for evaluating and monitoring the effects of Chinese fir monoculture plantations on soil quality. - Ecological Indicators 93: 547-554.

[60] Zhou, Z. C., Shangguan, Z. P., Zhao, D. (2006): Modeling vegetation coverage and soil erosion in the Loess Plateau Area of China. - Ecological Modelling 198(1-2): 263-268.

[61] Zhou, L., Shalom, A. D. D., Wu, P., He, Z., Liu, C., Ma, X. (2016): Biomass production, nutrient cycling and distribution in age-sequence Chinese fir (Cunninghamia lanceolata) plantations in subtropical China. - Journal of Forest Research 27: 357-368.

[62] Zhou, L., Shalom, A. D. D., Wu, P., Li, S., Jia, Y., Ma, X. (2015): Litterfall production and nutrient return in different-aged Chinese fir (Cunninghamia lanceolata) plantations in South China. - Journal of Forestry Research 26(1): 79-89. 